\title{
Peningkatan Prestasi Siswa melalui Pengembangan Profesional Guru: Suatu Tinjauan Literatur
}

\author{
Yuni Kasmawati \\ Manajemen, Universitas Budi Luhur, Indonesia \\ Korespondensi penulis: yuni.kasmawati@budiluhur.ac.id
}

\begin{abstract}
Currently, teachers are required to carry out their professional development. Because of professional development is a continuous learning process, so the teacher will learn the best way to adapt their teaching skills to fulfill student learning needs. The method used in this research is a literature review by utilizing reference sources in the form of journals, books, and other forms of publications. This study aims to examine the importance of teacher professional development in an educational environment that is used as a strategy to improve teacher capacity and student achievement. The results of this study indicate that professional development plays an important role in improving student achievement. However, increasing student achievement must be preceded by changes in teacher capacity, such as their knowledge, skills, attitudes, and beliefs that will bring changes in teaching and learning activities. Furthermore, teacher capacity can improve student achievement, so that in turn some improvements for school quality will be achieved to achieve overall educational success.
\end{abstract}

Keywords: Literature review; Professional development; Student achievement; Teacher capacity.

\begin{abstract}
Abstrak. Saat ini, guru dituntut untuk melakukan pengembangan profesional. Karena pengembangan profesional merupakan proses pembelajaran yang berkesinambungan, sehingga guru akan belajar cara terbaik untuk menyesuaikan kemampuan pengajaran dalam rangka memenuhi kebutuhan belajar siswa. Metode yang digunakan dalam penelitian ini adalah tinjauan literatur dengan memanfaatkan sumber referensi berupa jurnal, buku, maupun bentuk publikasi lainnya. Penelitian ini bertujuan untuk menelaah pentingnya pengembangan profesional guru dalam lingkungan kependidikan yang digunakan sebagai strategi untuk meningkatkan kapasitas guru dan prestasi siswa. Hasil penelitian ini menunjukkan bahwa pengembangan profesional berperan penting dalam meningkatkan prestasi siswa. Namun, peningkatan prestasi siswa tersebut harus didahului adanya perubahan kapasitas guru, seperti pengetahuan, ketrampilan, sikap, dan keyakinan mereka yang akan membawa perubahan dalam kegiatan belajar mengajar. Selanjutnya, kapasitas guru dapat meningkatkan prestasi siswa, sehingga pada gilirannya peningkatan kualitas sekolah akan tercapai dalam rangka menuju keberhasilan pendidikan secara menyeluruh.
\end{abstract}


Kata kunci: Kapasitas guru; Pengembangan profesional; Prestasi siswa; Tinjauan literatur.

Article Info:

Received: February 20, 2020

Accepted: May 12, 2020

Available online: July 15, 2020

DOI: http://dx.doi.org/10.30588/jmp.v10i1.648

\section{LATAR BELAKANG}

Pendidikan ditujukan agar peserta didik memiliki kekuatan spiritual keagamaan, kepribadian, pengendalian diri, akhlak mulia, kecerdasan, dan ketrampilan (Badan Pemeriksa Keuangan, 2020a). Peran guru dalam kependidikan sangat penting, mengingat guru mempunyai tugas utama mendidik, membimbing, mengajar, melatih, mengarahkan dan menilai, serta mengevaluasi peserta didik (Badan Pemeriksa Keuangan, 2020b). Namun, pada kenyataannya masih banyak guru di Indonesia kekurangan pengetahuan mata pelajaran dan ketrampilan pedagogis yang diperlukan untuk menjadi pendidik yang efektif. Selain itu, hasil belajar siswa dikategorikan buruk dan terdapat perbedaan ketrampilan dengan kebutuhan dunia kerja (Rosser, 2018).

Guru menjadi faktor kunci dalam menghasilkan pendidikan yang berkualitas, sehingga penyiapan guru profesional yang mampu mendidik akan menjadi sesuatu yang sangat penting (Pemerintah Provinsi Jawa Barat, 2019). Terkait dengan keberhasilan siswa dalam pendidikan, guru mempunyai peran utama. Guru tidak hanya menyampaikan ilmu yang dimilikinya kepada siswa atau yang disebut guru sebagai sumber belajar, tetapi guru juga berfungsi sebagai fasilitator yang mampu membuat materi pelajaran mudah diterima, sebagai pengelola yang mampu menciptakan suasana belajar yang kondusif untuk kegiatan belajar mengajar, sebagai demonstrator yang mampu menunjukkan sikap menginspirasi siswa, sebagai pembimbing yang mampu mengarahkan dalam mencapai cita-cita siswa, sebagai motivator yang menumbuhkan semangat dan motivasi siswa, sebagai evaluator yang mampu mengevaluasi keberhasilan siswa dan keberhasilan kegiatan pembelajaran. Contoh peran guru sebagai sumber belajar ditunjukkan oleh penelitian yang dilakukan Borko, Elliott, dan Uchiyama (2002) yang menyatakan bahwa keberadaan guru diharapkan dapat membantu siswa mengembangkan banyak pemahaman yang mengandung konten penting, mampu berekspresi dengan baik, dan mampu menunjukkan ketrampilan dan pemahaman baru. Konsekuensinya, guru perlu untuk meningkatkan kompetensinya.

Peningkatan kompetensi, seperti pengetahuan dan ketrampilan diperlukan untuk memfasilitasi kebutuhan siswa akan penalaran dan pemecahan masalah (Holland, 2005). Misalnya, guru bahasa Inggris perlu meningkatkan ketrampilan profesional dan pembaruan pengetahuan agar selaras dengan kebutuhan siswa yang senantiasa berubah, selaras dengan paradigma pendidikan, dan teknologi pengajaran (Diaz-Maggioli, 2003a). Ketrampilan-ketrampilan guru bahasa Inggris yang perlu dikuasai, antara lain ketrampilan yang berhubungan dengan pemahaman untuk mendengarkan, kemampuan berbicara, pemahaman bacaan, dan kemampuan menulis. Keselarasan dengan teknologi pengajaran dapat dilakukan dengan mengintegrasikan teknologi melalui pembuatan konten dan proses pembelajaran yang lebih informatif dan mudah diakses, serta dapat membuat siswa lebih aktif. Penggunaan open learning software maupun learning management 
system, seperti Moodle, Blackboard, Edmodo, dan Schoology, yang menawarkan fiturfitur interaktif dapat mendukung proses pembelajaran bahasa Inggris.

Salah satu upaya peningkatan ketrampilan dan pengetahuan tersebut dapat dilakukan melalui pengembangan profesional guru. Pengembangan profesional dapat dilakukan guru melalui pencarian ide-ide, baik melalui kegiatan seminar, kolega, maupun sumber profesional yang lain (Gumuselii \& Eryilmaz, 2011). Di Indonesia, pengembangan profesional guru dikuatkan melalui Undang-Undang nomor 14 tahun 2005 tentang Guru dan Dosen (Badan Pemeriksa Keuangan, 2020b). Undang-undang tersebut mewajibkan guru meningkatkan dan mengembangkan kompetensi maupun kualifikasi akademik secara berkesinambungan yang sejalan dengan ilmu pengetahuan, teknologi, dan seni. Program sertifikasi, pembentukan Pusat Kegiatan Guru (PKG), Kelompok Kerja Guru (KKG), dan Musyawarah Guru Mata Pelajaran (MGMP) merupakan bentuk lain dari upaya pemerintah dalam rangka meningkatkan profesionalisme guru melalui pengembangan kompetensinya.

Pengembangan profesional dapat memberikan manfaat tidah hanya bagi guru itu sendiri, tetapi juga siswa, bahkan sekolah secara keseluruhan. Misalnya, pengembangan profesional guru dapat mempengaruhi bagaimana guru mengajar di kelas melalui perubahan dalam mengajar (Garet, Porter, Desimone, \& Birman, 2001; Guskey \& Sparks, 2002; Knapp, 2003; Darling-Hammond, Wei, Andree, Richardson, \& Orphanos, 2009; Nabhani, Nicolas, \& Bahous, 2014) yang akan mengarah pada peningkatan prestasi siswa (Garet et al., 2001; Guskey \& Sparks, 2002; Desimone, Porter, Garet, Yoon, \& Birman, 2002; Knapp, 2003; Borko, 2004; Holland, 2005; Kafyulilo, 2014; Lin, Cheng, \& Wu, 2015; Akiba \& Liang, 2016; Lee, Longhurst, \& Campbell, 2017; Prast, WeijerBergsma, Kroesbergen, \& Luit, 2018) dan kapasitas sekolah yang meliputi pengetahuan, ketrampilan, disposisi pekerjaan, komunitas profesional, koherensi program, sumber daya teknis, dan kepemimpinan sekolah (Newmann, King, \& Youngs, 2000).

Terkait dengan tuntutan peningkatan standar kualitas kompetensi guru oleh pemerintah, peran utama guru dalam upaya mencapai keberhasilan pendidikan, kurangnya pengetahuan mata pelajaran, dan ketrampilan pedagogis guru, serta dampak positif pengembangan profesional guru, maka artikel ini bertujuan untuk mengkaji peran pengembangan profesional yang dilakukan oleh guru dalam rangka meningkatkan prestasi siswa. Banyak penelitian yang membahas mengenai pengaruh pengembangan profesional terhadap prestasi siswa, tetapi penelitian-penelitian tersebut lebih banyak dilakukan di luar Indonesia. Untuk itu, telaah literatur ini perlu dilakukan sebagai bahan referensi bagaimana pengembangan profesional guru yang efektif dilakukan di Indonesia agar mampu mendukung peningkatan prestasi siswa menuju peningkatan kualitas pendidikan. Pada akhirnya, pengembangan profesional guru tersebut perlu dilakukan oleh semua guru, baik pada jenjang pendidikan dasar, seperti PAUD (Pendidikan Anak Usia Dini), SD (Sekolah Dasar), dan SMP (Sekolah Menengah Pertama), maupun jenjang pendidikan menengah, yaitu SMA (Sekolah Menengah Atas) dan SMK (Sekolah Menengah Kejuruan) dalam rangka menuju keberhasilan pendidikan secara menyeluruh. Berdasarkan uraian latar belakang tersebut, penelitian ini bertujuan untuk menelaah pentingnya pengembangan profesional guru dalam lingkungan kependidikan yang digunakan sebagai strategi untuk meningkatkan kapasitas guru dan prestasi siswa. 


\section{KAJIAN TEORITIS}

\section{Pengembangan Profesional}

Pengetahuan yang dimiliki oleh guru merupakan sumber daya yang dimiliki oleh sekolah. Sumber daya tersebut berupa pengetahuan, yaitu sumber daya yang paling penting bagi sebuah organisasi, karena sumber daya tersebut tidak mudah ditiru dan berbasais pengetahuan yang kompleks, serta kapabilitasnya yang heterogen, sehingga organisasi mampu bersaing, seperti dinyatakan dalam Teori Knowledge-Based View atau KBV (Grant, 1996). Untuk itu, organisasi perlu mengembangkan pengetahuan baru untuk mencapai keunggulan kompetitifnya. Hal ini berlaku juga bagi organisasi di lingkungan kependidikan, khususnya organisasi pendidikan yang beorientasi bisnis. Pengembangan pengetahuan baru tersebut, selajutnya akan digunakan dan diimplementasikan untuk menunjang kinerja guru. Salah satu cara untuk mengembangkan pengetahuan baru adalah pengembangan professional guru.

Pengembangan profesional guru perlu dilakukan sebagai sarana untuk meningkatkan kompetensinya mengingat guru adalah tenaga profesional di bidang pendidikan. Beberapa definisi pengembangan profesional guru dari berbagai pendapat tercantum pada Tabel 1 berikut ini.

\section{Tabel 1. Definisi Pengembangan Profesional}

\begin{tabular}{|l|l|}
\hline \multicolumn{1}{|c|}{ Referensi } & \multicolumn{1}{c|}{ Pengembangan Profesional } \\
\hline Diaz-Maggioli (2003b) & $\begin{array}{l}\text { Proses pembelajaran yang berkelanjutan, ketika guru terlibat secara } \\
\text { sukarela untuk belajar bagaimana cara terbaik untuk menyesuaikan } \\
\text { pengajaran dengan kebutuhan belajar siswa. }\end{array}$ \\
\hline Marcelo (2009) & $\begin{array}{l}\text { Proses individu dan kolektif yang harus dicapai di tempat kerja guru } \\
\text { (sekolah) yang dipandang mampu berkontribusi terhadap } \\
\text { pengembangan ketrampilan profesional guru melalui berbagai } \\
\text { pengalaman, baik formal maupun informal. }\end{array}$ \\
\hline Day (2002) & $\begin{array}{l}\text { Semua pengalaman belajar alami dan kegiatan sadar serta terencana } \\
\text { yang bermanfaat secara langsung maupun tidak langsung bagi } \\
\text { individu maupun kelompok yang berkontribusi dalam meningkatkan } \\
\text { kualitas pendidikan. }\end{array}$ \\
\hline
\end{tabular}

Sumber: Sumber referensi terkait.

Pengembangan profesional wajib dilakukan oleh guru dan merupakan kewajiban maupun kesempatan yang berguna sebagai sarana untuk melakukan perubahan dan konfirmasi praktik saat ini (Diaz-Maggioli, 2003b), serta menjadi prioritas untuk meningkatkan pencapaian hasil belajar siswa (Bredeson \& Johansson, 2000), sehingga pengembangan profesional tersebut merupakan proses jangka panjang yang mencakup berbagai jenis peluang dan pengalaman yang direncanakan secara sistematis untuk merangsang perkembangan dan evaluasi guru (Marcelo, 2009).

Pengembangan profesional guru dilakukan atas dasar pendidikan yang terkait dengan pekerjaan guru dan dirancang untuk meningkatkan praktik dan hasilnya (Darling-Hammond \& McLaughlin, 2011). Peningkatan tersebut dikarenakan guru memperoleh dan mengembangkan pengetahuan, kompetensi, dan kecerdasan emosional yang digunakan sebagai dasar pemikiran profesional, perencanaan, dan praktik dengan anak-anak, remaja, maupun rekan kerjanya di setiap tahap kehidupan mengajar mereka 
(Day, 2002). Selanjutnya, pengembangan profesional guru, baik yang dilkaukan sendiri maupun secara bersama untuk meninjau, memperbarui, dan memperkuat komitmen mereka sebagai agen perubahan dengan tujuan pengajaran yang bermartabat.

Sparks dan Hirsh dalam laporan Marcelo (2009) mengidentifikasi perubahan yang dihasilkan dalam pengembangan profesional guru secara umum sebagai berikut:

1. Dari pengembangan profesional mengarah kepada pengembangan guru, kemudian berlanjut ke pengembangan organisasi.

2. Dari pengembangan profesional yang terpecah-pecah dan terputus ke arah pengembangan yang koheren, yaitu bekerja dalam rerangka tujuan yang jelas.

3. Dari pelatihan yang berbasis administrasi menuju ke arah yang lebih berfokus pada sekolah.

4. Dari perspektif yang berfokus pada kebutuhan guru hingga berfokus pada kebutuhan belajar siswa.

5. Dari pelatihan yang dikembangkan di luar sekolah sampai dengan berbagai jenis pengembangan profesional yang dilakukan di sekolah.

6. Dari pengembangan profesional terutama yang diarahkan kepada guru kepada jenis pengembangan lain yang diarahkan kepada semua orang yang terlibat dalam proses belajar siswa.

7. Dari pengembangan profesional yang diarahkan kepada guru di tingkat individual hingga penciptaan komunitas pembelajaran, yaitu setiap pimpinan, guru, karyawan, dan siswa menganggap diri mereka sebagai guru dan siswa.

Pengembangan profesional berkaitan erat dengan pencarian identitas profesional yang berkembang sepanjang karir guru dan dipengaruhi oleh sekolah, reformasi dan politik, komitmen pribadi, kesediaan untuk belajar dan mengajar, nilai-nilai dan kepercayaan, pengetahuan tentang mata pelajaran yang diajarkan, bagaimana guru mengajar, dan pengalaman mereka (Marcelo, 2009), sehingga pengembangan profesional mampu mempromosikan perubahan pada guru untuk tumbuh menjadi seorang profesional, di samping ia tumbuh sebagai individu. Model perubahan pada guru dalam pengembangan profesional melalui tahapan-tahapan seperti pada Gambar 1 berikut ini. Pada awalnya, pengembangan profesional membawa perubahan pada keyakinan dan pengetahuan guru. Perubahan tersebut akan memunculkan perubahan dalam praktik mengajar di kelas yang selanjutnya akan meningkatkan hasil belajar siswa (Marcelo, 2009).

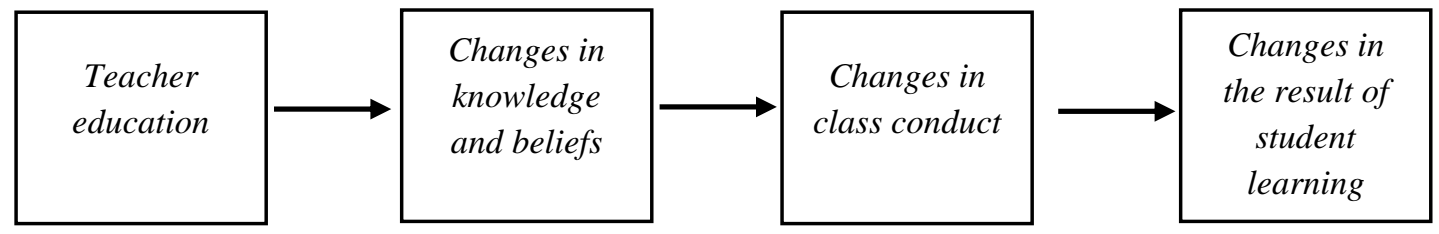

Sumber: Marcelo (2009).

\section{Gambar 1. Model Implisit Pengembangan Profesional Guru}

Model pengembangan profesional yang dikemukakan oleh Desimone (2009) mempunyai kemiripan dengan model pengembangan profesional yang dikemukakan oleh Marcelo (2009). Tahap-tahap model pengembangan profesional Desimone (2009) seperti pada Gambar 2, yaitu: (1) guru mengalami pengembangan profesional yang 
efektif; (2) pengembangan profesional mampu meningkatkan pengetahuan, ketrampilan, sikap, dan keyakinan guru; (3) guru menggunakan pengetahuan dan ketrampilan baru, sikap, serta keyakinan guru untuk meningkatkan isi praktik mengajar; dan (4) perubahan praktik mengajar akan mendoroang peningkatan pembelajaran siswa. Yoon, Duncan, Lee, Scarloss, dan Shapley (2007) menambahkan bahwa pada tahap pertama, pengembangan profesional harus berkualitas tinggi dalam aksi secara teori, perencanaan, disain, dan implementasi; tahap kedua, guru harus memiliki motivasi, kepercayaan, dan ketrampilan untuk menerapkan pengembangan profesional pada pengajaran di kelas; dan tahap ketiga, pengajaran guru ditingkatkan dengan pengembangan profesional yang akan meningkatkan pestasi siswa.

Model Desimone (2009) tersebut bertumpu pada dua jenis teori. Pertama, teori perubahan yang berhubungan dengan seberapa baik pengembangan profesional menimbulkan perubahan yang diinginkan dalam pengetahuan dan pengajaran guru. Kedua, teori pengajaran yang berhubungan dengan sejauh mana perubahan dalam pengajaran dapat meningkatkan pembelajaran siswa.

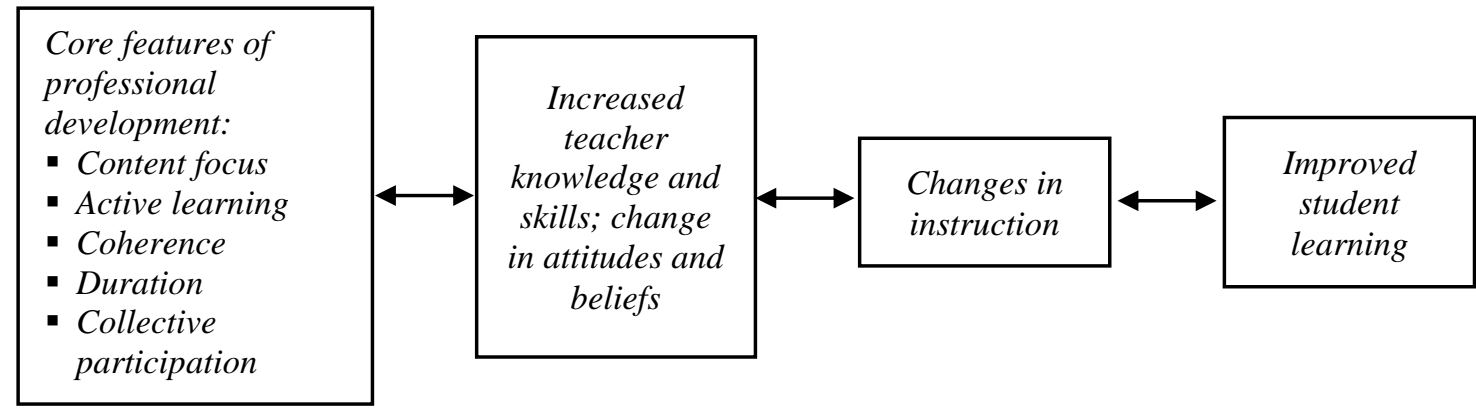

Sumber: Desimone (2009).

\section{Gambar 2. Rerangka Konseptual Inti Dampak Pengembangan Profesional terhadap Guru dan Siswa}

Dengan pandangan lain, Clarke dan Hollingsworth (2002) mengusulkan model pengembangan profesional yang membuat perubahan guru secara tidak linier, yaitu perubahan yang terjadi pada guru melalui mediasi dan proses refleksi pada empat tingkatan yang terdiri atas: domain pribadi (pengetahuan, kepercayaan, dan sikap guru), bidang praktik mengajar, konsekuensi dalam pembelajaran dan domain eksternal yaitu sumber informasi eksternal atau stimulus (Gambar 3.). Selanjutnya, Garet et al. (2001) melalui penelitiannya menyatakan bahwa ada tiga fitur inti dari kegiatan pengembangan profesional yang menunjukkan efek positif pada guru, yaitu: (1) fokus pada pengetahuan konten; (2) kesempatan untuk aktif belajar; dan (3) koherensi dengan kegiatan pembelajaran.

Model pengembangan profesional yang mengacu pada Gambar 1, Gambar 2, dan Gambar 3 menunjukkan bahwa pengembangan profesional guru mempunyai dampak meningkatkan prestasi siswa di sekolah. Untuk itu, pengembangan profesional tidak hanya membahas pembelajaran guru secara individual, tetapi juga dari segi kapasitas sekolah. Hal yang paling responsif dari kapasitas sekolah terhadap peningkatan kualitas sekolah melalui pengembangan profesional meliputi: (1) Pengetahuan, ketrampilan, dan disposisi guru. Guru harus kompeten dalam pengajaran dan penilaian, serta mempunyai 
harapan tinggi untuk keberhasilan pembelajaran siswa; (2) Komunitas profesional. Komunitas profesioanal yang kuat terdiri atas empat fitur, yaitu seperangkat tujuan bersama untuk pembelajaran siswa, kolaborasi dan tanggung jawab kolektif untuk mencapai tujuan, peluang guru untuk terlibat dalam kegiatan dan kebijakan sekolah, serta pemeriksaan profesional untuk mengatasi tantangan; (3) Koherensi program yang mencakup koherensi program pengajaran, fokus pada tujuan sekolah, dan berkelanjutan dari waktu ke waktu (Newmann et al., 2000).

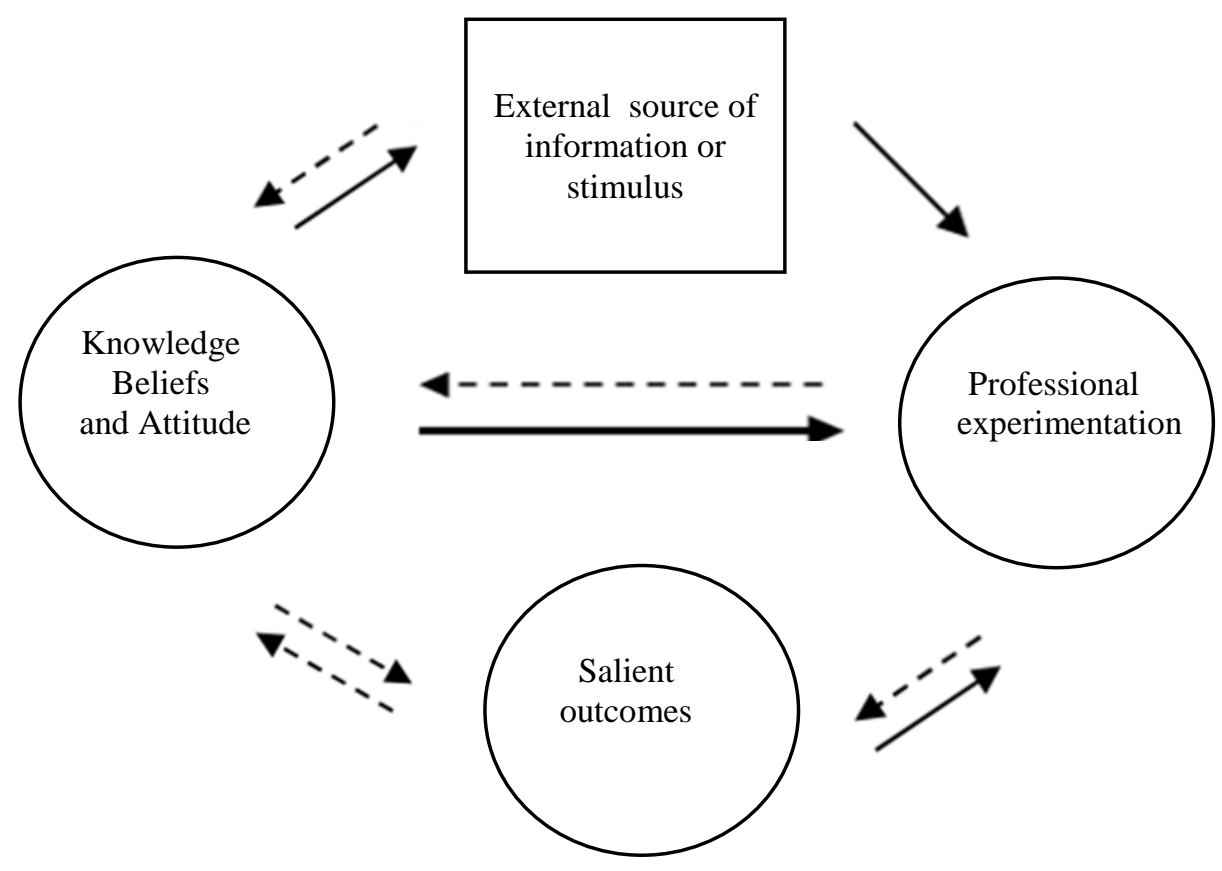

Sumber: Clarke dan Hollingsworth (2002).

Gambar 3. Model Pengembangan Profesional Inter-relasional

Di sisi lain, Guskey dan Sparks (2002) menjelaskan ada tiga faktor utama yang mempengaruhi kegiatan pengembangan profesional dalam meningkatkan pembelajaran siswa, yaitu: (1) Karakteristik konten, menyangkut pengetahuan baru, ketrampilan, dan pemahaman dasar upaya pengembangan profesional. Konten ini mencakup pemahaman tentang disiplin akademik, bagaimama siswa belajar, dan memperoleh pemahaman tentang ilmu tersebut; (2) Variabel proses mengacu pada bagaimana pengembangan profesional, tidak hanya jenis dan bentuk pengembangan profesionalnya saja, tetapi juga bagaimana merencanakan, mengorganisir, melaksanakan, dan menindaklanjutinya; dan (3) Karakteristik konteks yang mengacu pada siapa, kapan, di mana, dan mengapa pengembangan profesional dilakukan. Borko (2004) menjelaskan elemen-elemen kunci yang membentuk sistem pengembangan profesional guru, yaitu: (1) program dalam pengembangan profesional; (2) guru sebagai pembelajar dalam program pemgembangan profesional; (3) fasilitator yang membimbing guru dalam membangun praktik dan pengetahuan barunya, serta (4) konteks di mana pengembangan profesional itu terjadi. 


\section{Dampak Pengembangan Profesional terhadap Guru}

Pengembangan profesional melalui pelatihan memungkinkan individu mempelajari pengetahuan dan ketrampilan dan mentransfernya ke dalam praktik pengajaran mereka. Pelatihan tersebut akan membantu orang belajar mengenai bagaimana menjadi pembelajar yang lebih efektif melalui identifikasi hasil yang ingin dicapai dari pelatihan dan memilih komponen-komponen pelatihan, misalnya: pengetahuan dan teori, pemodelan, praktik, dan pelatihan dengan rekan kerja (Joyce \& Showers, 2003).

Dampak pengembangan profesional terhadap perubahan guru, seperti peningkatan pengetahuan pada program pengembangan, peningkatan kepercayaan dalam mengajar, peningkatan kesadaran tentang bidang pendidikan, penggunaan teknik pengajaran baru, dan penurunan perasaan terisolasi. Perubahan yang terjadi pada guru tersebut akan membuat pikiran terintegrasi dengan tindakan di berbagai situasi, baik dalam program pengembangan profesional, di ruang kelas, maupun di luar kelas. Perubahan tersebut tergantung pada: (1) faktor individual, seperti pengalaman, latar belakang, tingkat pendidikan, dan motivasi mengikuti pengembangan profesional; (2) faktor pengembangan profesional meliputi jumlah jam dan kualitas pengembangan profesional yang diikuti; dan (3) faktor program dan sistem yang meliputi struktur dan dukungan yang ditawarkan, akses ke waktu persiapan, situasi program, dan akses manfaat (Smith, Hofer, Gillespie, Solomon, \& Rowe, 2003). Selanjutnya, hasil penelitian Smith et al., (2003) menunjukkan bahwa pengembangan profesional berdampak pada perubahan guru, seperti pada praktik mengajarnya.

Penelitian yang dilakukan Garet et al. (2001) terhadap peserta pengembangan profesional di bidang matematika dan sains menyimpulkan bahwa guru yang mengikuti pengembangan profesional terkait langsung dengan pengalaman sehari-hari dan selaras dengan standar serta penilaian yang akan memperlihatkan kecenderungan guru mengubah praktik pengajaran, meningkatkan pengetahuan, dan ketrampilan mengajarnya. Guskey dan Sparks (2002) melaporkan bahwa kegiatan pengembangan profesional berpengaruh signifikan dan langsung terhadap pengetahuan dan praktik guru. Selanjutnya, pengetahuan dan praktik guru merupakan faktor utama yang mempengaruhi hubungan antara pengembangan profesional dan peningkatan pembelajaran siswa.

Pengembangan profesional yang intensif dan mencakup penerapan pengetahuan dalam perencanaan dan pengajaran guru akan mempengaruhi praktik mengajar yang pada gilirannya secara positif akan mempengaruhi prestasi siswa (Knapp, 2003). Selain itu, pengembangan profesional yang dirancang dengan baik dan efektif akan membantu guru menguasai konten, mengasah ketrampilan mengajar, mengevaluasi kinerjanya sendiri dan siswa, serta mampu mengadakan perubahan pengajaran dan pembelajaran jika diperlukan (Darling-Hammond et al., 2009).

\section{Dampak Pengembangan Profesional terhadap Prestasi Siswa}

Prestasi yang dicapai oleh siswa biasanya digunakan sebagai indikator keberhasilan siswa. Prestasi siswa tersebut bisa berupa hasil penilaian atau nilai ujian standar. Tidak menutup kemungkinan, hal tersebut bisa juga mencakup sikap siswa, kehadiran, nilai/skor pekerjaan rumah, maupun sikap di kelas (Guskey \& Sparks, 2002). Pengembangan profesional yang dilakukan oleh guru mampu mempengaruhi prestasi siswa melalui tiga langkah, sebagai berikut: (1) pengembangan profesional meningkatkan pengetahuan dan ketrampilan guru; (2) pengetahuan dan ketrampilan yang lebih baik akan mampu meningkatkan pengajaran di kelas; dan pada akhirnya (3) peningkatan pengajaran akan meningkatkan prestasi siswa. Jika salah satu langkah tersebut hilang atau le- 
mah, maka pembelajaran siswa yang lebih baik tidak dapat dicapai (Yoon et al., 2007).

Pengembangan profesional guru melalui kolaborasi guru secara efektif mampu meningkatan praktik pengajaran guru. Selanjutnya, peningkatan tersebut berdampak pada hasil belajar siswa di semua mata pelajaran dan kinerja sekolah. Hal tersebut mendasarkan pada kolaborasi guru yang dapat berfungsi sebagai tempat bagi guru untuk saling mengingatkan tentang peran mereka, praktik mengajar, dan meningkatkan pelajaran, bahan ajar, dan interaksi mereka dengan siswa. Empat bentuk utama kolaborasi guru untuk pengembangan profesional meliputi komunitas praktik, kelompok studi pelajaran, komunitas pembelajaran profesional, dan tim disain guru (Kafyulilo, 2013). Anto dan Coenders (2019) melaporkan bahwa program pengembangan profesional secara kolaboratif mempunyai dampak pada empat domain yang berujung pada siswa, yaitu:

1. Domain praktik, yaitu terjadinya peningkatan praktik pengajaran. Hal ini timbul karena guru melibatkan siswa lebih aktif dalam proses belajar mengajar, mendorong pembelajaran kolaboratif pada siswa, mengaitkan pengajaran dengan pengalaman kehidupan nyata siswa, merencanakan dan mengimlementasikan pelajaran, serta menggunakan pendekatan ketrampilan terintegrasi dalam pengajaran.

2. Domain konsekuensi yang merupakan tujuan akhir pengembangan profesional, yaitu meningkatkan keterlibatan siswa dalam proses pembelajaran, memotivasi siswa untuk belajar, dan memperkuat hubungan positif antara guru dan siswa.

3. Domain personal. Guru memperoleh penyegaran pengetahuan yang akan direfleksikan ke dalam praktik pengajaran, sehingga ia akan mendapatkan kepuasan profesional, meningkatkan harga diri guru, dan termotivasi untuk meningkatkan pembelajaran dan praktik.

Lumpe (2007) mengidentifikasi bahwa faktor-faktor yang terkait dengan pengembangan profesional guru berdampak pada prestasi siswa, antara lain umpan balik yang efektif, kerja sama, kolegialitas, pengembangan staf yang berorientasi praktik, budaya kepercayaan, dan hubungan bersama. Pencapaian perubahan guru dalam mengajar dan peningkatan prestasi siswa memerlukan pengembangan profesional yang didasarkan pada koherensi (Desimone et al., 2002), materi konten (Garet et al., 2001), berfokus pada praktik pengajaran (Borko, 2004), dan berkelanjutan dari waktu ke waktu (CochranSmith \& Lytle, 1999b). Di sisi lain, penelitian yang dilakukan Holland (2005) menyimpulkan bahwa ketika pengembangan profesional terkait langsung dengan program yang diajarkan guru, standar dan penilaian, fokus pada pengetahuan guru tentang materi pelajaran, dan bagaimana siswa memahami serta mempelajarinya, maka guru mempunyai kecenderungan untuk mengubah praktik mengajarnya. Selanjutnya, praktik mengajar mampu meningkatkan prestasi siswa.

Sementara itu, penelitian Lee et al. (2017) menunjukkan bahwa pengembangan profesional guru berpengaruh signifikan terhadap perubahan keyakinan pedagogis guru. Keyakinan pedagogis berkaitan dengan cara mengajar guru menggunakan teknologi dan kemampuan melaksanakan model pembelajaran inkuiri pada mata pelajaran sains. Pada akhirnya, keyakinan pedagogis tersebut berkorelasi terhadap prestasi siswa. Lin et al. (2015) meneliti hubungan antara program pengembangan profesional guru dengan pembelajaran siswa. Program pengembangan profesional dapat dilakukan melalui dialog profesional, pengembangan kurikulum, pengawasan sesama rekan, dan pembinaan sesa- 
ma teman. Prestasi siswa ditunjukkan melalui kelancaran siswa dalam membaca. Hasil penelitian tersebut juga menunjukkan pengembangan profesional berpengaruh signifikan terhadap prestasi siswa. Hal ini dimungkinkan karena pengetahuan dan ketrampilan baru yang didapatkan guru selama pengembangan profesional akan digunakan sebagai strategi untuk mengajar dan memenuhi kebutuhan siswa.

Penelitian untuk menguji efek pengembangan profesional berupa kegiatan pembelajaran formal dan informal guru terhadap prestasi siswa dilakukan oleh Akiba dan Liang (2016). Pengembangan profesional yang digunakan meliputi kolaborasi guru, program universitas, konferensi profesional, komunikasi informal, dan pembelajaran individu, sedangkan prestasi siswa dilihat dari nilai matematika. Hasil penelitian tersebut menunjukkan bahwa pengembangan profesional guru mampu meningkatkan prestasi siswa terutama pengembangan profesional berupa kolaborasi guru dan komunikasi informal. Peningkatan prestasi siswa tersebut dimungkinkan karena pengembangan profesional yang dilakukan guru bermanfaat dalam meningkatkan pengetahuan dan pengajaran, sehingga hal itu mengarah pada peningkatan prestasi siswa. Penelitian dengan hasil serupa oleh Prast et al. (2018) menguji efek program pengembangan profesional guru terhadap prestasi matematika siswa. Hasil penelitian mereka menyimpulkan bahwa pengembangan profesional berpotensi meningkatkan prestasi siswa.

\section{METODE PENELITIAN}

Analisis dalam penelitian ini menggunakan metode tinjauan literatur. Tujuan menggunakan tinjauan literatur, yaitu untuk menggambarkan, meringkas, mengevaluasi, mengklarifikasi dan atau mengintegrasikan konten terhadap temuan yang telah ada sebelumnya (Cooper, 1988), menghubungkan temuan baru dengan temuan sebelumnya, mengintegrasikan, dan menggeneralisasikan temuan lintas bidang ilmu (Randolph, 2009). Langkah-langkah tinjauan literatur dalam penelitian ini mengacu pada pendapat Cronin, Ryan, \& Coughlan (2008), yaitu (1) memilih topik ulasan; (2) mencari literatur; (3) mengumpulkan, membaca, dan menganalisis literature; (4) menulis ulasan/mempresentasikan temuan; dan (5) referensi.

Data dikumpulkan melalui teknik kepustakaan, baik berupa buku maupun hasil penelitian yang telah dipublikasikan dalam jurnal ilmiah atau pun bentuk publikasi lainnya. Dalam penelitian ini, definisi pengembangan profesional mengacu pada pendapat yang dikemukakan oleh Gruenert (2000, 2005) dan Gumuselii dan Eryilmaz (2011), yaitu pengembangan profesional menggambarkan sikap guru untuk mendapatkan ideide baru dan sumber profesional lainnya untuk peningkatan mutu pembelajaran di sekolah, seperti peningkatan kualitas guru dan prestasi siswa.

\section{HASIL DAN PEMBAHASAN}

Penelitian-penelitian terdahulu menunjukkan bahwa pengembangan profesional yang dilakukan oleh guru memberi dampak tidak hanya pada guru, tetapi juga pada siswa seperti ditunjukkan pada Tabel 2 berikut ini. Berdasarkan hasil penelitian yang tersaji pada Tabel 2 menunjukkan bahwa pengembangan profesional yang dilakukan oleh guru memberi dampak positif terhadap guru maupun siswa. Hal ini tidak menutup kemungkinan bahwa pengembangan profesional dalam jangka panjang akan mampu meningkatkan kapasitas sekolah secara menyeluruh. Untuk itu, pengembangan profesi- 
onal harus mengarah pada pertanyaan: (1) apa yang diketahui guru dan apa yang harus diketahui guru; (2) pengetahuan apa yang penting untuk profesi guru dan pengembangan profesionalnya; dan (3) bagaimana pengetahuan tersebut dapat diperoleh.

Cochran-Smith dan Lytle (1999a) menjelaskan bahwa pengetahuan-pengetahuan yang harus dimiliki oleh guru adalah pengetahuan untuk praktik, pengetahuan dalam praktik, dan pengetahuan tentang praktik. Pengetahuan untuk praktik berfungsi dalam pengaturan praktik dan mengarah pada pembelajaran berupa konten, teori pendidikan, dan strategi pembelajaran, sehingga mengajar menjadi lebih efisien. Pengetahuan dalam praktik atau pengetahuan dalam tindakan merupakan sesuatu yang diketahui guru, implisit dalam praktik, refleksi pada praktik dan pembelajaran, serta narasi praktik. Pengetahaun dalam praktik diperoleh guru melalui pengalaman dan diskusi, ketika guru belajar dan merefleksikannya. Pengetahuan tentang praktik dibangun secara kolektif secara intern di dalam sekolah yang terdiri atas guru yang terlibat dalam proyek pengembangan sekolah, pelatihan, atau penelitian kolaboratif.

Tabel 2. Dampak Pengembangan Profesional

\begin{tabular}{ll}
\multicolumn{1}{c}{ Pada guru } & \multicolumn{1}{c}{ Pada Siswa } \\
\hline $\begin{array}{l}\text { Peningkatan pengetahuan, ketrampilan, dan } \\
\text { perubahan mengajar guru (Garet } \text { et al., 2001). }\end{array}$ & $\begin{array}{l}\text { Meningkatkan pembelajaran siswa (Guskey \& } \\
\text { Sparks, 2002). }\end{array}$ \\
\hline $\begin{array}{l}\text { Peningkatan pengetahuan dan praktik guru } \\
\text { (Guskey \& Sparks, 2002). }\end{array}$ & $\begin{array}{l}\text { Mempengaruhi prestasi siswa (Knapp, 2003), } \\
\text { prestasi nilai matematika (Akiba \& Liang, 2016; } \\
\text { Prast } \text { et al., 2018). }\end{array}$ \\
\hline $\begin{array}{l}\text { Peningkatan praktik mengajar (Nabhani } \text { et al., } \\
\text { 2014). }\end{array}$ & $\begin{array}{l}\text { Meningkatkan prestasi siswa (Holland, 2005; } \\
\text { Desimone } \text { et al., 2002; Garet } \text { et al., 2001; Borko, } \\
\text { 2004). }\end{array}$ \\
\hline $\begin{array}{l}\text { Mempengaruhi praktik mengajar (Knapp, 2003). } \\
\text { Berdampak positif pada hasil belajar siswa di } \\
\text { semua mata pelajaran (Kafyulilo, 2013). }\end{array}$ \\
$\begin{array}{ll}\text { Membantu guru menguasai konten, ketrampilan } \\
\text { mengajar, dan mengadakan perubahan mengajar } \\
\text { (Darling-Hammond } \text { et al., 2009). }\end{array}$ & $\begin{array}{l}\text { Berkorelasi positif dengan prestasi siswa (Lee } \text { et } \\
\text { al., 2017). }\end{array}$ \\
\hline $\begin{array}{l}\text { Perubahan keyakinan pedagogis guru (Lee } \text { et al., } \\
\text { 2017). }\end{array}$ & Kelancaran membaca siswa (Lin et al., 2015). \\
\hline $\begin{array}{l}\text { Sumber: Referensi terkait. } \\
\end{array}$ &
\end{tabular}

Berdasarkan alasan bahwa pengembangan profesional memberikan dampak positif terhadap guru, seperti pengetahuan dan ketrampilan, maka Holland (2005) menyarankan bahwa yang perlu diperhatikan dalam pengembangan profesional adalah pengembangan profesional harus berfokus pada pengetahuan konten dan koherensi. Koherensi mencakup pengembangan atas apa yang telah dipelajari guru, menyelaraskan pengembangan profesional dengan standar dan penilaian yang ditetapkan, dan mendorong komunikasi antarguru. Selain dua hal tersebut, rentang waktu (lamanya pelatihan dari waktu ke waktu) dan jam kontak (jumlah jam yang dihabiskan dalam pengembangan profesional) juga harus diperhatikan. Sementara itu, pengembangan profesional perlu dikelola dengan baik agar memperoleh hasil sesuai yang diharapkan, sehingga pengembangan profesional dapat berjalan secara efektif sebagai pembelajaran profesional terstruktur yang menghasilkan perubahan praktik guru dan peningkatan hasil belajar siswa (Darling-Hammond et al., 2017). 
Pengelolaan pengembangan profesional melalui perencanaan dan implementasi akan mampu mengatasi hambatan dan rintangan, sehingga pengembangan profesional menjadi lebih efektif dan berkualitas. Untuk itu, pengembangan profesional harus mampu: (1) menciptakan peluang guru untuk terlibat dalam pembicaraan substantif tentang praktik dan gagasan pengajaran, serta terlibat dalam diskusi kritis tentang ide-ide rekan kerja; (2) memastikan bahwa pengetahuan guru tentang materi pelajaran, pengajaran, dan pembelajaran dapat dibagikan dan dihargai; (3) merancang pengembangan profesional, yaitu guru dapat mengakui kekurangan tanpa dianggap merasa kurang; dan (4) mengatasi keluhan guru dan membuat katalog apa yang dilakukan guru selama mengajar (Bechtel \& O'Sullivan, 2006). Di samping itu, pengembangan profesional memerlukan bimbingan, dukungan, dan kepemimpinan koordinator materi pelajaran, kepala sekolah, koordinator kurikulum dan pengawas sekolah sebagai pengambil keputusan terakhir tetntang masalah yang berkaitan dengan pembelajaran siswa dan praktik pengajaran guru (Spillane et al., 2001).

Selain itu, Guskey (2003) dan Guskey dan Yoon (2008) menjelaskan bahwa pengembangan profesional dapat berjalan efektif apabila ada beberapa hal yang perlu mendapatkan perhatian, seperti peningkatan konten guru dan pengetahuan pedagogis. Peningkatan ini dapat membantu guru memahami lebih dalam terhadap konten yang diajarkan dan bagaimanan siswa memperoleh pengetahuan dan ketrampilan konten tersebut. Selain itu, penyediaan waktu dan sumber daya yang memadai juga perlu mendapatkan perhatian. Pengembangan profesional dapat efektif apabila tersedia dalam waktu yang lama, diatur dengan baik, terstruktur, sengaja diarahkan, dan berfokus pada konten maupun pedagoginya. Di samping itu, promosi kolegialitas dan pertukaran kolaboratif sangat diperlukan. Kolaborasi harus terarah, terstruktur, dan dipandu dengan jelas. Pada akhirnya, pengembangan profesional juga harus mencakup prosedur evaluasi dan tindak lanjut.

Desimone dan Garet (2015) mengusulkan setidaknya ada lima fitur agar pengembangan profesional dapat memberikan dampak efektif dalam meningkatkan praktik mengajar dan pembelajaran siswa, yaitu: Pertama, fokus pada konten memberi pengertian bahwa kegiatan difokuskan pada konten materi pelajaran dan bagaimana siswa mempelajari konten tersebut. Kedua, pembelajaran aktif berupa kesempatan bagi guru untuk mengamati, menerima umpan balik, menganalisis pekerjaan siswa, dan membuat presentasi. Ketiga, koherensi yang menyangkut isi, sasaran, dan kegiatan harus konsisten dengan kurikulum dan sasaran sekolah, pengetahuan dan kepercayaan guru, kebutuhan siswa, serta kebijakan sekolah dan pemerintah. Keempat, durasi yang berkelanjutan yaitu kegiatan pengembangan profesional berlangsung sepanjang tahun ajaran. Kelima, partisipasi kolektif yaitu kelompok guru dari kelas, mata pelajaran, maupun sekolah yang sama turut berpartisipasi dalam kegiatan pengembangan profesional secara bersama-sama untuk membangun komunitas pembelajaran interakif.

Sementara itu, Patton et al. (2015) berpendapat bahwa pengembangan profesional yang efektif melibatkan delapan fitur, yaitu keterlibatan guru (fitur 1-4), praktik mengajar (fitur 5-7), dan pembelajaran siswa (fitur 8). Fitur 1-4 meliputi pengembangan profesional yang didasarkan pada kebutuhan dan minat guru, pengembangan profesional yang mengakui bahwa belajar adalah proses sosial, pengembangan profesional merupakan peluang kolaboratif dalam komunitas belajar para pendidik, dan pengembangan profesional dilaksanakan secara berkelanjutan. Fitur 5-7 mencakup pengembangan profesional memperlakukan guru sebagai pelajar aktif, pengembangan profesional mening- 
katkan ketrampilan pedagogis guru dan pengetahuan konten, serta pengembangan profesional yang difasilitasi dengan kepedulian. Fitur 8 adalah pengembangan profesional yang berfokus pada peningkatan hasil belajar siswa.

Di sisi yang lain, Darling-Hammond et al. (2017) mengidentifikasi elemenelemen model pengembangan profesional yang efektif, yaitu berfokus pada konten, menggabungkan pembelajaran aktif, dukungan kolaborasi, memberikan dukungan oleh ahli dan pembinaan, menawarkan umpan balik dan refleksi, serta durasi yang berkelanjutan. Fokus pada konten memiliki makna bahwa pengembangan profesional harus berfokus pada strategi pengajaran yang terkait dengan konten kurikulum yang mendukung pembelajaran guru. Pembelajaran guru yang akfif melibatkan guru secara langsung dalam merancang dan mencoba strategi mengajar serta memberi kesempatan untuk terlibat dalam implementasi rancangan tersebut. Dukungan kolaborasi diperlukan agar pengembangan profesional berjalan efektif dengan menciptakan ruang bagi guru untuk berbagi ide dan berkolaborasi dalam pembelajaran. Selain dukungan kolaborasi, penggunaan model praktik yang efektif juga diperlukan, yaitu model tersebut dapat memberikan visi yang jelas bagi guru terkait praktik pengajaran terbaik. Pengembangan profesional memerlukan pembinaan dan dukungan oleh ahli melalui sistem berbagi keahlian tentang konten dan praktik berbasis bukti yang difoluskan pada kebutuhan guru. Tidak kalah pentingnya, umpan balik dan refleksi dengan menyediakan waktu bagi guru untuk memikirkan, menerima masukan, dan membuat perubahan praktik guru dengan memfasilitasi refleksi dan mengumpulkan umpan baliknya. Pada akhirnya, durasi yang berkelanjutan dengan memberikan waktu yang cukup kepada guru untuk belajar, berlatih, serta menerapkan dan merefleksikan strategi baru yang memfasilitasi perubahan praktik guru akan menjadikan pengembangan profesional berjalan efektif.

Smith et al. (2003) merekomendasikan, agar pengembangan profesional memberikan dampak perubahan pada guru, maka pengembangan profesional perlu dilihat dasi sisi pimpinan, pengembangan profesional itu sendiri, dan guru. Dilihat dari sudut pimpinan, pihak pimpinan lembaga/pemerintah perlu memperbaiki kondisi kerja guru, memberikan kompensasi guru yang mengikuti pengembangan profesional, dukungan untuk berpartisipasi dengan rekan sesama program dan kesempatan untuk mendiskusikan apa yang dipelajari setelah melaksanakan pengembangan profesi, menetapkan harapan/tujuan di tingkat lembaga/pemerintah, dan memastikan program harus dipelajari oleh semua guru. Dari sisi program pengembangan profesional, perlu dipastikan bahwa program pengembangan profesional berkualitas tinggi, menawarkan berbagai model pengembangan profesional, menjelaskan partisipasi guru pada model pengembangan profesional tersebut, membantu guru mendapatkan ketrampilan dalam membangun teori pengajaran yang baik untuk keberhasilan siswa, serta menambah kegiatan dalam pengembangan profesional untuk membantu guru menyusun strategi pengambilan keputusan. Dari sisi guru, mereka harus mempertimbangkan cara terbaik dalam belajar dan perlu memahami model pengembangan profesional yang sesuai dengan kebutuhan, memikirkan dengan jelas apa yang ingin dipelajari dalam pengembangan profesional, mengembangkan filosofi dan teori pengajaran yang baik untuk keberhasilan siswa, serta bekerjasama dengan kolega lain untuk meningkatkan kondisi kerja. 


\section{KESIMPULAN DAN SARAN}

Berdasarkan tinjauan literatur, pengembangan profesional berdampak positif terhadap prestasi siswa. Dampak pengembangan profesional pada guru terlihat pada peningkatan pengetahuan dan ketrampilan, dan mampu meningkatkan prestasi siswa. Mengingat pengembangan profesional berdampak tidak hanya bagi guru tetapi juga bagi siswa, maka beberapa hal terkait program pengembangan profesional perlu mendapatkan perhatian lebih, yaitu peningkatan pengetahuan tentang materi pelajaran yang diajarkan guru, peningkatan pemahaman guru tentang pemikiran siswa dalam materi pelajaran, dan menyelaraskan pengembangan profesional sesuai kurikulum dan pengalaman kerja guru. Untuk itu, pembuat kebijakan harus bisa memastikan bahwa pengembangan profesional guru berfokus pada materi yang diajarkan guru dengan mempertimbangkan koherensinya dan mempertimbangkan kemudahan bagi guru untuk mengintregrasikan pengetahuan tersebut ke dalam proses pengajaran.

Hal penting berikutnya adalah menyelaraskan peluang pengembangan profesional dengan pengalaman kerja, materi, dan penilaian kurikulum. Pengembangan profesional juga harus menyediakan waktu yang memadai dan memperluas kesempatan belajar bagi guru. Pimpinan dan kepemimpinan berperan kunci dalam mendukung dan mendorong guru untuk menerapkan pengembangan profesional di kelas. Sementara itu, pemerintah daerah/sekolah perlu memiliki sistem untuk mengevaluasi dampak pengembangan profesional pada praktik mengajar dan pembelajaran siswa, memberikan umpan balik, dan melakukan pemantauan secara berkala

Selanjutnya, perhatian juga perlu diberikan kepada guru, karyawan, dan orang tua siswa yang memiliki peran penting dalam keberhasilan pembelajaran siswa dan kemampuan mereka dalam memenuhi tanggung jawab secara efektif yang sangat ditentukan oleh kualitas pengembangan profesional (Guskey \& Sparks, 2002). Pada akhirnya, pengembangan profesional yang direncanakan dan diimplementasikan dengan baik serta ditindaklanjuti harus dianggap sebagai komponen penting dalam sistem pengajaran dan pembelajaran komprehensif yang dapat mendukung siswa untuk mengembangkan pengetahuan, ketrampilan, dan kompetensi yang dibutuhkan untuk berkembang di abad ke-21.

\section{Implikasi}

Pengembangan profesional mempunyai dampak positif pada pengetahuan dan ketrampilan guru. Keterikatan tersebut dapat dijelaskan dengan menggunakan Knowlegde Based View (Grant, 1996). Pengetahuan dan ketrampilan yang dimiliki oleh guru merupakan aset sekolah yang senantiasa harus ditingkatkan agar mereka mampu bersaing. Ketika pengembangan profesional digunakan sebagai sarana untuk meningkatkan pengetahuan dan ketrampilan guru, maka guru akan menggunakan dan mengimlememtasikan dalam proses pembelajaran. Dampak selanjutnya, pengembangan profesional akan meningkatkan kinerja guru, yang salah satunya dapat diukur melalui prestasi siswa.

Berdasarkan hasil telaah ini, pengembangan profesional guru berdampak positif terhadap prestasi siswa. Namun, dampak tersebut didahului dengan peningkatan pengetahuan dan ketrampilan guru. Terkait dengan hal tersebut, pihak sekolah hendaknya mendukung dan menfasilitasi pengembangan profesional yang dilakukan guru dan mengimplementasikannya dalam proses pembelajaran di sekolah. Selain itu, pihak penyelenggara pengembangan profesional perlu menyelaraskan konten pengembangan profesional dengan materi pelajaran/kurikulum, kebutuhan siswa, bersifat berkelanjutan, dan memiliki tindak lanjutnya. 


\section{DAFTAR REFERENSI}

Akiba, M., \& Liang, G. (2016). Effects of Teacher Professional Learning Activities on Student Achievement Growth. Journal of Educational Research, 109(1), 99-110. https://doi.org/10.1080/00220671.2014.924470.

Anto, A. G., \& Coenders, F. (2019). Teacher Learning in Collaborative Professional Development: Changes in Teacher and Student Practices. In Collaborative Curriculum Design for Sustainable Innovation and Teacher Learning (pp. 229-247). Springer. https://doi.org/10.1007/978-3-030-20062-6.

Badan Pemeriksa Keuangan (2020a). Undang-Undang Republik Indonesia Nomor 20 Tahun 2003 tentang Sistem Pendidikan Nasional. Diakses 23 April 2020 dari https://peraturan.bpk.go.id/Home/Details/43920/uu-no-20-tahun-2003.

Badan Pemeriksa Keuangan (2020b). Undang-Undang Republik Indonesia Nomor 14 Tahun 2005 tentang Guru dan Dosen. Diakses 23 April 2020 dari https://peraturan.bpk.go.id/Home/Details/40266/uu-no-14-tahun-2005.

Bechtel, P. A., \& O'Sullivan, M. (2006). Chapter 2: Effective Professional Development-What We Now Know. Journal of Teaching in Physical Education, 25(4), 363-378. https://doi.org/10.1123/jtpe.25.4.363.

Borko, H. (2004). Professional Development and Teacher Learning: Mapping the Terrain. Educational Researcher, 33(8), 3-15. https://doi.org/10.3102/0013189X033008003.

Borko, H., Elliott, R., \& Uchiyama, K. (2002). Professional Development: A Key to Kentucky's Educational Reform Effort. Teaching and Teacher Education, 18, 969-987.

Bredeson, P. V., \& Johansson, O. (2000). The School Principal's Role in Teacher Professional Development. Journal of In-Service Education, 26(2), 385-401. https://doi.org/10.1080/13674580000200114.

Clarke, D., \& Hollingsworth, H. (2002). Elaborating a Model of Teacher Professional Growth. Teaching and Teacher Education, 18(8), 947-967. https://doi.org/10.1016/S0742-051X(02)00053-7.

Cochran-Smith, \& Lytle, S. L. (1999a). The Teacher Research Movement: A Decade Later. Educational Researcher, 28(7), 15-25. https://doi.org/10.3102/0013189X028007015.

Cochran-Smith, M., \& Lytle, S. L. (1999b). Relationships of Knowledge and Practice: Teacher Learning in Communities. Review of Research in Education, 24(1), 249305. https://doi.org/10.3102/0091732x024001249.

Cooper, H. M. (1988). Organizing Knowledge Syntheses: A Taxonomy of Literature Reviews. Knowledge in Society, 1(1), 104-126. https://doi.org/10.1007/BF03177550.

Cronin, P., Ryan, F., \& Coughlan, M. (2008). Undertaking a Literature Review: A Stepby-Step Approach. British Journal of Nursing, 17(1), 38-43. https://doi.org/10.1177/107808747000500401.

Darling-Hammond, L., Hyler, M. E., Gardner, M., \& Espinoza, D. (2017). Effective Teacher Professional Development. Palo Alto: Learning Policy Institute. 
Darling-Hammond, L., \& McLaughlin, M. W. (2011). Policies That Support Professio-nal Development in an Era of Reform. Phi Delta Kappan, 92(6), 81-92. https://doi.org/10.1177/003172171109200622.

Darling-Hammond, L., Wei, R. C., Andree, A., Richardson, N., \& Orphanos, S. (2009). Professional Learning in the Learning Profession: A Status Report on Teacher Development in the United States and Abroad. National Staff Development Council. https://doi.org/10.1006/jfbi.2002.2063.

Day, C. (2002). Developing Teachers: The Challenges of Lifelong Learning. Journal of Chemical Information and Modeling (Vol. 53). Taylor \& Francis e-Library. https://doi.org/10.1017/CBO9781107415324.004.

Desimone, L. M. (2009). Improving Impact Studies of Teachers' Professional Development: Toward Better Conceptualizations and Measures. Educational Researcher, 38(3), 181-199. https://doi.org/10.3102/0013189X08331140.

Desimone, L. M., \& Garet, M. S. (2015). Best Practices in Teachers' Professional Development in the United States. Psychology, Society and Education, 7(3), 252263. https://doi.org/10.25115/psye.v7i3.515.

Desimone, L. M., Porter, A. C., Garet, M. S., Yoon, K. S., \& Birman, B. F. (2002). Effects of Professional Development on Teachers' Instruction: Results from a Three-year Longitudinal Study. Educational Evaluation and Policy Analysis, 24 (2), 81-112. https://doi.org/10.3102/01623737024002081.

Diaz-Maggioli, G. H. (2003a). Options for Teacher Development. English Language Teaching Forum, 2(41), 5-12.

Diaz-Maggioli, G. H. (2003b). Professional Development for Language Teachers. EDO-FL, 03-03. ERIC Digest. https://doi.org/10.1093/elt/ccl014.

Garet, M. S., Porter, A. C., Desimone, L., \& Birman, B. F. (2001). What Makes Professional Development Effective? Results From a National Sample of Teachers. American Educational Research Journal, 38(4), 915-945.

Grant, R. M. (1996). Toward A Knowledge-Based Theory of the Firm. Strategic Management Journal, 17(Winter Special Issue), 109-122.

Gruenert, S. (2000). Shaping a New School Culture. Contemporary Education, 71(2), 14 18.

Gruenert, S. (2005). Correlations of Collaborative School Cultures with Student Achievement. NASSP Bulletin, 89(645), 43-55. https://doi.org/10.1177/019263650508964504.

Gumuselii, A. I., \& Eryilmaz, A. (2011). The Measurement of Collaborative School Culture (CSC) on Turkish Schools. New Horizons in Education, 59(2), 13-26.

Guskey, T. R. (2003). What Makes Professional Development Effective? Phi Delta Kappan, 84(10), 748-750. https://doi.org/10.1177/003172170308401007.

Guskey, T. R., \& Sparks, D. (2002). Linking Professional Development to Improvements in Student Learning. Annual Meeting of the American Educational Research Association.

Guskey, T. R., \& Yoon, K. S. (2008). What Works in Professional Development. Phi Delta Kappan, 90(7), 495-500. https://doi.org/10.1177/003172170909000709.

Holland, H. (2005). Teaching Teachers: Professional Development to Improve Student Achievement. American Educational Research Association (Vol. 3). Washington, DC. 
Joyce, B. R., \& Showers, B. (2003). Student Achievement Through Staff Development. National College for School Leadership. Retrieved from http://books.google.com/books?hl=en\&lr=\&id=MtBj2sJXHGwC\&pgis=1.

Kafyulilo, A. C. (2013). Professional Development through Teacher Collaboration: An Approach to Enhance Teaching and Learning in Science and Mathematics in Tanzania. Africa Education Review, 10(4), 671-688. https://doi.org/10.1080/18146627.2013.853560.

Knapp, M. S. (2003). Chapter 4: Professional Development as a Policy Pathway. Review of Research in Education, 27(1), 109-157. https://doi.org/10. 1016/B978-0-12-3820303.00004-0.

Lee, H., Longhurst, M., \& Campbell, T. (2017). Teacher Learning in Technology Professional Development and Its Impact on Student Achievement in Science. International Journal of Science Education, 39(10), 1282-1303. https://doi.org/10.1080/09500693.2017.1327733.

Lin, S.-C., Cheng, W.-W., \& Wu, M. (2015). Uncovering a Connection between the Teachers' Professional Development Program and Students' Learning. Journal of Education and Practice, 6(23), 66-74.

Lumpe, A. T. (2007). Research-Based Professional Development: Teachers Engaged. Journal of Science Teacher Education, 18, 125-128. https://doi.org/10.1007/s10972006-9018-3.

Marcelo, C. (2009). Professional Development of Teachers: Past and Future. Educatio-nal Sciences Journal, (8), 5-20. https://doi.org/10.1163/9789087907419.

Nabhani, M., Nicolas, M. O. D., \& Bahous, R. (2014). Principals' Views on Teachers' Professional Development. Professional Development in Education, 40(2), 228-242. https://doi.org/10.1080/19415257.2013.803999.

Newmann, F. M., King, M. B., \& Youngs, P. (2000). Professional Development that Addresses School Capacity: Lessons from Urban Elementary Schools. American Journal of Education, 259-299.

Patton, K., Parker, M., \& Tannehill, D. (2015). Helping Teachers Help Themselves: Professional Development that Makes a Difference. NASSP Bulletin, 99(1), 26-42. https://doi.org/10.1177/0192636515576040.

Pemerintah Provinsi Jawa Barat (2019). Guru Faktor Kunci Keberhasilan Pendidikan Berkualitas. Diakses 15 Maret 2020 di https://jabarprov.go.id/index.php/news/ 33740/2019/07/19.

Prast, E. J., Weijer-Bergsma, Eva Van Kroesbergen, E. H., \& Van Luit, J. E. H. (2018). Differentiated Instruction in Primary Mathematics: Effects of Teacher Professional Development on Student Achievement. Learning and Instruction. https://doi.org/10.1016/j.learninstruc.2018.01.009.

Randolph, J. J. (2009). A Guide to Writing the Dissertation Literature Review. Practical Assessment, Research and Evaluation, 14(13), 1-13.

Rosser, A. (2018). Beyond Aacces: Making Indonesia's Education System Work. Sidney: Lowy Institute.

Smith, C., Hofer, J., Gillespie, M., Solomon, M., \& Rowe, K. (2003). How Teachers Change: A Study of Professional Development in Adult Education. Retrieved from http://www.ncsall.net/fileadmin/resources/research/report25.pdf. 
Spillane, J. P., Halverson, R., \& Diamond, J. B. (2001). Investigating School Leadership Practice: A Distributed Perspective. Educational Researcher, 30(3), 23-28. https://doi.org/10.3102/0013189x030003023.

Yoon, K. S., Duncan, T., Lee, S. W.-Y., Scarloss, B., \& Shapley, K. L. (2007). Reviewing the Evidence on How Teacher Professional Development Affects Student Achievement. Regional Educational Laboratory Southwest, 033. https://doi.org/10.3102/0002831208328088. 